\title{
Analysis on Principle of Sovereign Judicial Immunity in Municipal Courts in International Laws
}

\author{
Askar Jalalian, Zohreh Moradi* \\ Department of Law, Payame Noor University, PO BOX 19395 - 3697, Tehran, Iran \\ *E-mail address: Zohreh.moradi57@yahoo.com
}

\begin{abstract}
In this article principle of sovereign judicial immunity, developments and changes on this principle and change of principle of immunity from absolute to limited have been studied. Judicial immunity of foreign state in municipal courts is of the most important issues in international and national law. Judicial immunity in national law is a special situation which immunes holders from prosecution and exercising legal punishments and disturbance of government officials and international judicial immunity contains mentioned characteristics in international arena. Immunity is one of the principles of general international law which prevents summoning of a foreign state to municipal state courts. Absolute immunity which was considered as a dominant method in early $20^{\text {th }}$ century gradually changed to limited immunity doctrine according which, acknowledger state has no commitment about granting immunity to exercise incumbency of state and exercising limited immunity would lead to sovereignty exercise.
\end{abstract}

Keywords: Judicial immunity; Limited immunity; Absolute immunity; Jure gestionis and jure imperii; Municipal courts; International law

\section{INTRODUCTION}

Although today sovereign immunity could establish its place among rules and gain conventional status, but it seems change of immunity from absolute to limited has not still been finished and everyday limited immunity is presented in a new and narrower meaning. This movement is in accordance with macro developments of international relationships and everyday domain of sovereignty of states is reduced. General principle of state sovereignty has been accepted in all countries but general tendency in most of the countries of the world changes from absolute immunity to limited immunity. Now in this article we deal with principle of immunity and its change process from absolute immunity to limited immunity and we find that in order to establish concept of limited immunity lots of documents have been edited and lots of countries have accepted principle of immunity but with changing acceptance procedure from absolute to limited they only accept and conduct principle of immunity on exercising sovereignty exercise. 


\section{CONCEPT OF SOVEREIGN IMMUNITY PRINCIPLE}

Subject of immunity is one of the important topics of international law. Although sovereign judicial immunity in international law is directly related to exercise or not to exercise of adjudicative jurisdiction of domestic courts but is different from it. In this immunity, municipal courts of states are prevented from assuming jurisdiction on foreign states except in exceptional cases. However in sovereign judicial immunity in national laws, judicial courts are prevented from assuming jurisdiction on their respective states (Kadkhodai \& Daei, 2011). Principle of judicial immunity against municipal courts has firstly appeared in domain of relationships of states. There is no doubt that granted advantages and immunities to states is based on principle of sovereign equality of states and is under shelter of principle of reciprocal transaction which reflects mutual respect of sovereignties (Zamani, 1999). Due to close relation between sovereign immunity and equality of sovereignty, some lawyers believe that immunity should not be sought in common law but it should directly be interpreted from concept of sovereignty and it should be known as expression of respect to sovereignty of states and considering principle of equality (Mousavi, 2006). Sovereignty is like a centre of authority from which other jurisdictions and domestic powers have been branched and are subject to it. Command monopoly, popularity of jurisdictions, and observing principle of equality are of characteristics of sovereignty (Mollayi, 2005). Terminologically speaking, the term immunity was first appeared in commercial treaty between France and Turkey in April 29 $9^{\text {th }}, 1861$. Then it has been used in International Convention for the Unification of Certain Rules concerning the Immunity of State-owned Vessels in April 10 ${ }^{\text {th }}, 1926$ (Taghizadeh Ansari, 2007). In "Amid Persian Dictionary" Persian equivalent for immune means kept and conserved and equivalent for immunity has been interpreted as to be immune and safe (Amid, 1995).

The concept of international immunity exists from distant past and political officials always and everywhere had immunity however international immunity is a new concept in modern international law. Any country or its high-ranking government officials in another country have some privileges according to international law and those privileges are called immunity. Judicial immunity is based on exemption of its user from obeying rules which is exercised in a country about jurisdiction of courts (Ziyaii Beygdeli, 2001). There are several definitions of immunity, e.g. immunity means that its holder should be immune from prosecution of law and state officials. In other words law and officials exercising it could not prosecute its holder (Sadr,1992). In another definition it has been told that "immunity is a right holders of which are immune from criminal, civil, and administrative prosecution, based on law, about all their actions while conducting their duties (Musazadeh, 1992). Immunity means exemption from responsibility about domestic acts in international system. A person who holds this right could rely on it if necessary. Therefore judicial immunity is a limitation conducted by international law on jurisdiction of courts of a government (Taghizadeh Ansari, 2007). Immunity is one of the major elements of international law. In a system where all its bases have almost been established on co-existence of independent sovereign states, some strategies should have been made to prevent states from intervening in one another's domestic affairs (Ansari,2004). Rule of immunity is based on sovereignty of states since sovereignty has two faces. The first necessary expression of sovereignty is the principle of exclusive jurisdiction of state on domestic domain without which, sovereignty is meaningless. Based on this principle any government has the right of legislative, executor, and judicial authority in its lands (Forcese, 2007).

Exterior manifestation of sovereignty is called independence. Equality of the countries is a result of their independence (Falsafi, 1991). 


\section{PASSING FROM PRINCIPLE OF ABSOLUTE IMMUNITY TO LIMITED IMMUNITY}

In era before establishment of state-nation, countries were under rule of kings, emperors, and rulers. Kings had widespread powers to govern the territory under their sovereignty. At those times separation of powers was not as same as today's concept therefore courts were under authority of kings. In other words kings were making laws themselves and were supervising its execution. "Sovereign immunity in a foreign country has been accepted since distant past based on international conventions and comity and it doesn't make any difference if head of the country is a king or a president, but it includes any authority who practically holds this standing (Khanlari Almoshiri, 2009). Consequently as a result of the belief that basically "king makes no mistake" and "he is over the rules" in both domestic and international fields immunity and absolute advantages were granted to kings, without any reason which could be justifiable today. After the peace of Westphalia in 1648, and change in social concepts in $18^{\text {th }}$ century especially affected by French Revolution, government gradually changed from private to public and concept of government was formed in accordance with today's meanings. After formation of abstract concept of government such an attitude vanished or better to say, faded. Gradually literature of immunity changed from immunity of rulers to immunity of state (Abdullahi \& Shafe, 2007). Laws supervising state immunity have undergone lots of changes in order to accordance to economical facts of today's life (Hooman \& Zaydel, 2000).

Before formation of state-nation that is when societies were governed in feudal system, feudal rulers didn't exercise jurisdiction on other rulers who were equal to them, based on the principle that equals could not exercise sovereignty on other person who is equal as well. This doctrine was used to observe dignity and to keep peace among them (Lyons, 1956). After peace of Westphalia, concept of sovereignty was result of strong units of state-nation and was the base of international law which was benefited to keep existence of these units and by increase in threats against this power institution, law doctrine dealt with increasing absoluteness of this concept. Although with change in social concepts in $18^{\text {th }}$ century especially affected by French revolution and emergence of national sovereignties in their modern form government was changed from its private form to public form and became origin of vast changes such as change from sovereignty of rulers to sovereignty of state, but it seems that especial immunity of rulers spread to state (Abdullahi \& Shafe, 2007). Gradually principle of sovereigns' absolute immunity lost its accordance with time circumstances. In this period, considering vast development of international marketing and necessity for compensating ruins consequence of World War, states entered to trade market and practically conducted activities which were not possible before either, or were mostly in monopoly of private sector.

Therefore the theory of absolute immunity which was mostly in accordance with era of limitation of state activities to only sovereignty activities, faded away (Abdullahi \& Shafe, 2007). Therefore during $20^{\text {th }}$ century developments in international relationships considering principle of international cooperation, changes in social life of human and unique growth of state activities lead to doubt in absolute immunity doctrine (Shaw, 2005). Professor Getari historically relates the roots of state immunity to lack of personal untouchability of rulers and their ambassadors when they were in a foreign country (Caplan, 2003). Therefore comprehensive evaluation of judicial procedure, some of contractual regulations, efforts for editing conventional regulations by unofficial institutions, and writings of international law show that it is not possible to consider unlimited or absolute immunity theory as a conventional international rule. But this does not mean abolition of principle of immunity since today there is no state in the world that absolutely ignores immunity of other states. Briefly it is possible 
to conclude that practically since World War I there is a movement to grant limited immunity to foreign states in judicial procedure and international conventions although this movement finally has reached a conclusion in middle years of $20^{\text {th }}$ century after World War II and has abolished absolute immunity theory and has replaced it with limited immunity theory (Abdullahi \& Shafe, 2007).

European Convention on State Immunity known as BAL convention was edited by countries of European Council considering theory of state limited immunity. This subject was declared in preface of the convention and will of states to form a legal regime to exercise limited immunity was emphasized. In other words this convention approved a change for exercising more limited judicial immunity (Kek Din et al, 2003). Function of unofficial organizations in this issue is in accordance with procedure of abolition of states' absolute immunity. Study draft of Harvard Law School in 1932 has declared the finish of reign of absolute theory by supporting theory of limited immunity. Therefore in order to establish the concept of limited immunity lots of documents were edited among which, it is possible to mention to laws of state immunity in America, France, Italy, in national level, and European Convention on State Immunity in regional level, and United Nations Convention on Jurisdictional Immunities of States and Their Property in international level.

\section{DISTINCTION BETWEEN ENFORCEMENT GOVERNANCE AND ENTERPRISE}

After World War II theory of limited immunity was established. The structure of this theory is based on distinction between jure gestionis and jure imperii of state. According to it granting immunity is only limited to jure imperii (Abdullahi \& Shafe, 2007). Jure imperii is a set of acts which are naturally conducted by state and due to relation with sensitive political issues, are only modified and executed by state. Naturally, these acts could not be put to the municipal courts of a country but jure gestionis are those acts that could be conducted equally by state and persons (Moghtader, 1994). Developments in international relations according to principle of international cooperation, changes in social life of human, and unique growth of state activities especially in trading issues lead to doubt in this case and modification of absolute immunity doctrine (Shaw, 2005). In September the $2^{\text {nd }}, 2004$ United Nations Convention on Jurisdictional Immunities of States and Their Property was approved by general assembly. Approval of convention shows formation of a global consensus to support legal theory of limited immunity for civil proceedings. In other words global society practically declared abolition of theory of state absolute immunity forever by approving this document (Mousavi, 2006).

Those who are for doctrine of limited immunity assign immunity to only general activities, a concept which almost is related to acts of general power or accepted acts in framework of mission of general services. Doctrine of limited immunity has lead municipal judicial authorities to distinguish between activities of foreign countries in national land that is distinction between jure gestionis and jure imperii (Ziyaii \& Beygdeli, 2001). Recognition criterion for jure gestionis and jure imperii is not always accurate. Some consider nature of act and some consider aim of act as recognition criterion (Sorayai, 2003). If we act as aim criterion we will witness increase in state judicial immunity since any act could lead to a sovereignty aim. On the other hand considering nature criterion as basis, would threaten territory of state immunity (Pingel, 2006). But logic of convention seeks for a combination of both theories. 
Procedure of countries and some approved documents in this case show using a criterion or both simultaneously.

On the other hand some acts which are exclusively in authority of state such as legislation, ruling domestic affairs of a country, and affairs related to armed forces have been considered as jure imperii of state (Robert, 1987). Today it is possible to claim that according to judicial procedure, international treaties and doctrine of state absolute immunity has abolished and has no ability to be defended. Lots of judicial decisions have been made by courts in various points of the world neglecting absolute immunity and have considered exceptions to it (Malcom, 1993). Although there is no doubt that principle of absolute immunity has no place in conventional international law but this does not mean abolition of immunity since today there is no state in the world that ignores immunity of other states (Abdullahi \& Shafe, 2007). In all countries general principle of immunity has been accepted but general tendency in most of the countries is towards change of immunity from absolute to limited, as most countries such as Italy, Germany, America, and England, first tended to absolute immunity, but now immunity issue is only considered if acts of subject of dispute have not trading nature.

\section{BASICS OF PRINCIPLE OF SOVEREIGN JUDICIAL IMMUNITY}

In explanation of the concept of sovereign immunity knowing its basics is of high importance. Therefore sovereign immunity has been justified based on different principles. Concepts of sovereignty, independence, and equality are joined concepts which have been defined as principles of state immunity. Therefore it is possible to conclude that one of the effects of independence or equality of states is duty of municipal courts in exercising jurisdiction on states. Exercising jurisdiction by courts of states against each other will have severe dangers for their sovereignty so will of states to their immunity and reliance on principle of sovereignty is justifiable (Falsafi, 1991). Based on theory of representation of legal practices immunity of high-ranking governmental authorities and other representatives is that they are spokesmen of their state and nation and based on the principle of sovereignty equality no king will be follower of rules of other king. Therefore state representatives also should not be followers of other rules (Sadr, 2005).

Montesquieu writes in his book spirit of rules: Political laws enjoin that any guilty should be trialed in criminal and civil courts of the country where he is and be monitored by its authorities. On the other hand based on international law kings and heads of states send representatives as ambassadors to other kings' courts but natural reasons don't let these representatives to obey kings and courts of the country to which they have been sent. The reason is that mentioned representatives are representative of commitments of their respective kings and this promise of commitment should be free without any hindrance (Montesque, 1983). Of other basics it is possible to mention to principle of state superiority in national arena. Rule of sovereign immunity is by-product of principle of inherent superiority and law of national governor or its sovereignty in national arena. Since national governor is not prosecuted in municipal courts superiority of national governor spreads beyond territory borders and in order to preserve its dignity and independence in international arena, state is not also prosecuted by municipal courts of other states. Therefore practical necessity of state immunity resulted from avoidance of disrespect to independent state (Tajani, 2012). 


\section{CONCLUSIONS}

Principle of state equality is considered as one of the basic principles in international relationships according to which, any state is immune from judicial jurisdiction of other states. Rights of state immunity is a conventional international law according to which, any state could not investigate another independent state in its courts. Based on the principle that there is no domination for equals on each other, states are benefited from immunity principle and based on this, states should not exercise judicial jurisdiction on other states. First countries were under reign of kings and rulers. After change in sovereignty from rulers to sovereignty of state most of immunity attitudes were changed. Concept of state judicial immunity has changed based on international developments.

Of these developments it is possible to mention to change of immunity from absolute to limited. Therefore comprehensive evaluation of judicial procedure and efforts for editing conventional regulations show that it is not possible to consider unlimited or absolute immunity theory as a conventional international rule. The reason for designing limited immunity is development of role of states in field of economy and business activities. Basis of limited immunity theory relies on distinction between jure gestionis and jure imperii of the state. According to it, immunity is only limited to jure imperii. Today most of the countries have followed limited immunity doctrine. Most of the countries have accepted general principle of immunity but with change in immunity from absolute to limited granting immunity is only limited to jure imperii. Therefore range of state immunity has somehow decreased and with distinction in jure gestionis and jure imperii they can only hold immunity in domain of jure imperii. Therefore today place and range of immunity has somehow decreased and states should be responsible for their actions in some cases.

\section{References}

[1] Pingel I., Legal Journal 35 (2006) 433.

[2] Taghizadeh Ansari M., Research Center for Humanities 64 (2007) 28.

[3] Taghizadeh Ansari M. (2004). Terminology of international law, French, Farsi, English. Tehran: Dadgar publication.

[4] Sorayai H. (2003). Public International Law. Tehran: Ghomes publication.

[5] Khanlari Almoshiri A. (2009). Immunities of the International Criminal. Tehran: Jungle publication.

[6] Zamani G., Institute of Legal Studies and Research of Knowledge 4 (1999) 231.

[7] Malcom Sh. (1993). International law, Translated by Waqar, M. H. Tehran: Information publication.

[8] Sadr J. (1992). Diplomatic and Consular Rights. Tehran: Tehran University Press.

[9] Sadr J. (2005). Diplomatic and Consular Rights. Tehran: Tehran University Press.

[10] Ziyaii Beygdeli M. R., Study of Law and Politics 4 (2001) 97-98.

[11] Amid H. (1995). Amid Persian culture, Tehran: Amir Kabir Publication. 
[12] Abdullahi M., Shafe M. (2007). State immunity in international law. Tehran: Department Presidential Press Office.

[13] Falsafi H. (1991). Cognitive International Law, Journal of Legal Studies, Martyr Beheshti University: 90.

[14] Kadkhodai A. A., Daei A., Journal of International Law 23 (2011) 23-31.

[15] Musazadeh R. (1992). International rights organizations. Tehran: Pazhng Publication.

[16] Mousavi A., Journal foreign policy 4 (2006) 874.

[17] Moghtader H. (1994). Public International Law.Tehran: Political and International Studies.

[18] Mollayi Y. (2005). Sovereignty and international law. Tehran: Science publication.

[19] Montesque Sh. (1983). Spirit Alqvanyn, Translated by Mohandesi,A.Tehran: Tehran University Publication.

[20] Kek Din N., Dibeh P., Peleh A. (2003). Public International Law, Translated by Habibi, H. Tehran: Information publication.

[21] Hooman F., Zaydel A. (2000). International Economic Law, Translated by Zamani G., Tehran: Diffusion of knowledge.

[22] Tajani Sh. B. (2012). Court precedent United States of America concerning the immunity of foreign governments and their property, Master's thesis, International Law: 17.

[23] Caplan L. M. (2003). State Immunity Human Rights and Jus Cogens, A Critique of the Normative Hierarchy Theory App, (35763/9): 745.

[24] Forcese C. (2007). De-immunizing torture, Reconciling Human Rights and state Immunity, McGill Law Journal.

[25] Lyons A. B. (1956). The Avoidance of hardships Resulting from the Doctrine of Sovereign Immunity. Transactions of the Grotius Society vol 42.

[26] Shaw M. (2005). International Law, Cambridge University press.

[27] Robert B. (1987). The International Law Dictionary, Oxford. 